\title{
Analisis Faktor Yang Berhubungan Dengan Kejadian Anemia Pada Ibu Hamil Di Puskesmas Sanrobone Kabupaten Takalar
}

\author{
Analysis of factors related to the incidence of anemia in pregnant women at the Sanrobone \\ Health Center in Takalar District
}

\author{
Ayu Sunarti. $\mathbf{S}^{1}$, Andi Kartini ${ }^{2}$ \\ Akademi Kebidanan Graha Ananda Palu \\ Email:Ayu_sunarti@yahoo.com
}

\begin{abstract}
Abstrak
Penelitian ini bertujuan untuk menganalisis Faktor Yang Berhubugan Dengan Kejadian Anemia Pada Ibu Hamil Di Puskesmas Sanrobone Kabupaten Takalar, seperti pola makan, pantangan makanan, konsumsi tablet fe dan Asupan gizi ibu hamil. Jenis penelitian yang digunakan adalah observasional dengan pendekatan cross sectional study yaitu untuk mengetahui hubungan variabel Independen dengan variabel dependen yang diamati pada periode waktu yang sama. Lokasi dan waktu Penelitian ini dilaksanakan di Puskesmas Sanrobone Kabupaten Takalar dan dilakukan pada bulan Desember 2016 - Januari 2017. Populasi dalam penelitian ini adalah semua ibu hamil yang datang memeriksakan kehamilannya sebanyak 97 Orang dan Sampel dalam penelitian ini adalah dari keseluruhan ibu hamil yang mengalami kejadian Anemia 60 Orang. Dengan teknik pengambilan sampel menggunakan accidental sampling (ada pada saat penelitian berlangsung). Instrument penelitian ini berupa kuesioner. Data dianalisis dengan menggunakan uji chi suare (X2). Hasil penelitian menunjukkan bahwa pola makan (nilai $\mathrm{p}=0$,757) tidak berhubungan dengan kejadian anemia pada ibu hamil. Sedangkan pantangan makanan (nilai $p=0,005$ ), konsumsi tablet Fe (nilai $p=0,000$ ), asupan Gizi (nilai $p=0,000$ ) berhubungan dengan kejadian anemia pada ibu hamil. Dari ketiga variabel tersebut variabel yang paling berhubungan dengan kejadian anemia pada ibu hamil adalah variabel pemberian tablet Fe dengan nilai expected = 7.712.
\end{abstract}

Kata Kunci : Pola Makan, Pantangan Makanan, Konsumsi Tablet Fe dan Asupan Gizi.

\begin{abstract}
This study aims to analyze factors relating to the incidence of anemia in pregnant women at the Sanrobone Health Center in Takalar Regency, such as diet, dietary restrictions, tablet consumption and nutritional intake of pregnant women. The type of research used was observational with a cross sectional study approach, namely to determine the relationship of Independent variables with the dependent variable observed in the same time period. Location and time This study was conducted at Sanrobone Health Center in Takalar District and was conducted in December 2016 - January 2017. The population in this study were all 97 pregnant women who came to have their pregnancies and the sample in this study were all pregnant women who experienced anemia. 60 people. With the sampling technique using accidental sampling (there was at the time of the study). The instrument of this research is a questionnaire. Data were analyzed using the chi suare test (X2). The results showed that diet $(p$ value $=0.757)$ was not related to the incidence of anemia in pregnant women. While dietary restrictions $(p$ value $=$ $0.005)$, consumption of Fe tablets ( $p$ value $=0,000)$, Nutrition intake ( $p$ value $=0,000)$ were associated with the incidence of anemia in pregnant women. Of the three variables, the variable most associated with the incidence of anemia in pregnant women is the variable giving Fe tablets with expected values $=7.712$.
\end{abstract}

Keywords: Diet, Food Abstinence, Fe Tablet Consumption and Nutrition Intake. 


\section{PENDAHULUAN}

Anemia dapat menyebabkan produktifitas kerja menurun, bayi lahir dengan berat badan rendah, bayi lahir dengan premature, abortus preeklamsia, menyulitkan persalinan bahkan mengakibatkan kematian perinatal dan kematian ibu yang melakukan persalinan, karena anemia daya tahan tubuh menurun terhadap serangan berbagai macam penyakit terutama penyakit infeksi.

World Health Organisation (WHO) menunjukkan bahwa prevalensi anemia pada ibu hamil tahun 2007 sebanyak 55\% yang bermakna tinggi pada trimester III dibandingkan dengan trimester I dan II kehamilan, sedangkan pada tahun 2008 terdapat 30\% dari 5 milyar penduduk dunia menderita anemia. Anak-anak dan wanita hamil paling banyak terkena, dengan prevalensi global masing-masing sebanyak 43\% [1].

Menurut survey kesehatan nasional tahun 2010 menunjukkan bahwa angka kejadian anemia pada ibu hamil sebesar 36,1\%. Kondisi ini mengatakan bahwa anemia cukup tinggi di Indonesia. Dilaporkan juga bahwa prevalensi anemia di Indonesia adalah 705, ini berarti 7 dari 10 wanita hamil menderita anemia. Berdasarkan survei penduduk tahun 2010 diperkirakan bahwa untuk seluruh golongan umur, 230.000.000 penduduk menderita anemia. Berarti secara nasional 50\% dari penduduk Indonesia berisiko menderita anemia [2].

Provinsi Sulawesi Selatan berdasarkan Survey Kesehatan Rumah Tangga pada tahun 2013 menunjukkan bahwa prevalensi anemia gizi khususnya pada ibu hamil berkisar 45,5\% sampai 71,2\% dan pada tahun 2007 menjadi 76,175. pada tahun 2008 ibu hamil yang menderita anemia meningkat sebanyak 94,12\% diantaranya yang menderita anemia ringan sebanyak 40,56\%, anemia sedang sebanyak 43,67\%, dan anemia berat sebanyak 9,89\% [3].

Berdasarkan data riset Dinas Kesehatan Dasar Kabupaten Takalar menunjukkan bahwa ibu hamil yang memeriksakan kehamilannya 87,5\% yang lebih rendah dari angka Provinsi Sulawesi Selatan sebanyak 90,2\%, dan cakupan pemeriksaan kehamilan lebih tinggi di perkotaan dibanding di pedesaan serta jenis pemeriksaan kehamilan yang jarang dilakukan pada ibu hamil adalah pemeriksaan hemoglobin sebanyak 46,7\% .

Pelayanan antenatal pelayanan yang diberikan ibu hamil secara berkala untuk menjaga kesehatan ibu dan janinnya. Hal ini meliputi pemeriksaan kehamilan dan upaya koreksi terhadap penyimpangan yang ditemukan, pemberian intervensi dasar (misalnya pemberian imunisasi TT dan tablet Fe) serta mendidik dan memotivasi ibu agar dapat merawat dirinya dan mempersiapkan persalinannya.

Data yang diperoleh dari Puskesmas Sanrobone Kabupaten Takalar tahun 2012 menunjukkan ibu hamil yang menderita anemia sebanyak 10\% dari 97 ibu hamil. Berdasarkan uraian tersebut diatas maka pentingnya dilakukan penelitian mengenai anemia dan analisis faktor yang berhubungan dengan anemia seperti : pola makan, pantangan makanan, konsumsi tablet Fe dan Asupan gizi ibu hamil.

\section{METODE}

Jenis penelitian yang digunakan adalah observasional dengan pendekatan cross sectional study yaitu untuk mengetahui hubungan variabel Independen dengan variabel dependen yang diamati pada periode waktu yang sama [4]. Populasi dalam penelitian ini adalah semua ibu hamil yang datang memeriksakan kehamilannya sebanyak 97 Orang di Puskesmas Sanrobone Kabupaten Takalar Tahun 2016 Dengan besar sampel 60 Orang. teknik pengambilan sampel dalam penelitian ini menggunakan accidental sampling (ada pada saat penelitian berlangsung).

\section{HASIL}

Hasil analisis data disajikan dalam bentuk tabel yang dilengkapi dengan penjelasan sebagai berikut: 
1. Hubungan Pola Makan dengan Kejadian Anemia Pada Ibu Hamil

Tabel 1. Hubungan Pola Makan dengan Kejadian Anemia Pada Ibu Hamil Di Puskesmas Sanrobone Kabupaten Takalar Tabel 1 Distribusi Karakteristik Subjek Penelitian

\begin{tabular}{|c|c|c|c|c|c|c|c|c|}
\hline \multirow{3}{*}{ Variabel } & \multicolumn{4}{|c|}{ Status Ibu Hamil } & \multirow{2}{*}{\multicolumn{2}{|c|}{ Total }} & \multirow{3}{*}{$X^{2}$} & \multirow{3}{*}{$p$} \\
\hline & \multicolumn{2}{|c|}{ Anemia } & \multicolumn{2}{|c|}{ Tidak Anemia } & & & & \\
\hline & $\mathbf{n}$ & $\%$ & $\mathbf{n}$ & $\%$ & $\mathbf{n}$ & $\%$ & & \\
\hline \multicolumn{9}{|l|}{ Pola makan } \\
\hline $\begin{array}{ll}\text { Tidak } & \text { Men- } \\
\text { gonsumsi } & \end{array}$ & 29 & 64.4 & 16 & 35.6 & 45 & 100 & & \\
\hline Mengonsumsi & 9 & 60.0 & 6 & 30.0 & 15 & 100 & & \\
\hline Total & 38 & 63.4 & 22 & 36.6 & 60 & 100 & & \\
\hline
\end{tabular}

Sumber : Data Primer, 2016

Tabel 1 menunjukkan bahwa dari 45 ibu hamil yang memiliki pola makan kurang menderita anemia. Sedangkan dari 15 ibu hamil yang memiliki pola makan menderita anemia. Hasil analisis statistik diperoleh nilai Q $^{2}$ hitung $(0,096)<]^{2}$ tabel $(3,841)$ dan nilai $p(0,757)>0,05$. Ini berarti pola makan tidak berhubungan dengan kejadian anemia pada ibu hamil di Puskesmas Sanrobone Kabupaten Takalar 2016. Rerata HLA-G Kelompok abortus dan Kelompok hamil normal

2. Hubungan Pantangan Makanan dengan Kejadian Anemia Pada ibu hamil

Tabel 2. Hubungan Pantangan Makan dengan Kejadian Anemia Pada Ibu Hamil Di Puskesmas Sanrobone Kabupaten Takalar

\begin{tabular}{|c|c|c|c|c|c|c|c|c|}
\hline \multirow{3}{*}{ Variabel } & \multicolumn{4}{|c|}{ Status Ibu Hamil } & \multirow{2}{*}{\multicolumn{2}{|c|}{ Total }} & \multirow{3}{*}{$X^{2}$} & \multirow{3}{*}{$p$} \\
\hline & \multicolumn{2}{|c|}{ Anemia } & \multicolumn{2}{|c|}{ Tidak Anemia } & & & & \\
\hline & $\mathbf{n}$ & $\%$ & $\mathbf{n}$ & $\%$ & $\mathbf{n}$ & $\%$ & & \\
\hline Pantangan Makanan & & & & & & & \multirow{4}{*}{8.031} & \multirow{4}{*}{0.005} \\
\hline $\begin{array}{ll}\begin{array}{l}\text { Tidak } \\
\text { gonsumsi }\end{array} & \text { Men- } \\
\end{array}$ & 32 & 74.4 & 11 & 25.6 & 43 & 100 & & \\
\hline Mengonsumsi & 6 & 35.3 & 11 & 64.7 & 17 & 100 & & \\
\hline Total & 38 & 63. & 22 & 36.7 & 60 & 100 & & \\
\hline
\end{tabular}

Sumber : Data Primer, 2016

Tabel 2 menunjukkan bahwa dari 43 ibu hamil yang menyatakan pantangan makanan tidak mengkonsumsi, terdapat yang menderita anemia sebanyak 74,4\%. Sedangkan dari 17 ibu hamil yang menyatakan pantangan makanan mengkonsumsi, terdapat yang menderita anemia sebanyak 35,3\%. Hasil análisis statistik diperoleh nilai Q $^{2}$ hitung $(8,031)>0^{2}$ tabel $(3,841)$ dan nilai $p(0,005)<0,05$. Ini berarti pantangan makanan berhubungan dengan kejadian anemia pada ibu hamil di Puskesmas Sanrobone Kabupaten Takalar 2016. Rerata Kadar Serum HLAG Pada karakteristik, 
3. Hubungan Konsumsi Tablet Fe dengan Kejadian Anemia Pada ibu hamil

Tabel 3. Hubungan Konsumsi Tablet Fe dengan Kejadian Anemia Pada Ibu Hamil Di Puskesmas Sanrobone Kabupaten Takalar

\begin{tabular}{|c|c|c|c|c|c|c|c|c|}
\hline \multirow{3}{*}{ Variabel } & \multicolumn{4}{|c|}{ Status Ibu Hamil } & \multirow{2}{*}{\multicolumn{2}{|c|}{ Total }} & \multirow{3}{*}{$X^{2}$} & \multirow{3}{*}{$p$} \\
\hline & \multicolumn{2}{|c|}{ Anemia } & \multicolumn{2}{|c|}{ Tidak Anemia } & & & & \\
\hline & $\mathbf{n}$ & $\%$ & $\mathbf{n}$ & $\%$ & $\mathbf{n}$ & $\%$ & & \\
\hline Konsumsi Tablet Fe & & & & & & & \multirow{4}{*}{16.407} & \multirow{4}{*}{0.000} \\
\hline Tidak Teratur & 33 & 80.5 & 8 & 1.5 & 41 & 100 & & \\
\hline Teratur & 5 & 26.3 & 14 & 73.7 & 19 & 100 & & \\
\hline Total & 38 & 63.3 & 47 & 36.7 & 60 & 100 & & \\
\hline
\end{tabular}

Sumber : Data Primer, 2016

Tabel 3 menunjukkan bahwa dari 41 ibu hamil yang tidak teratur mengkonsumsi tablet fe, terdapat yang menderita anemia sebanyak 80,5\%. Sedangkan dari 19 ibu hamil yang teratur mengkonsumsi tablet fe, terdapat yang menderita anemia sebanyak 26,3\%, Hasil analisis statistik diperoleh nilai ? $^{2}$ hitung $(16,407)>0^{2}$ tabel $(3,841)$ dan nilai $p(0,000)<0,05$. Ini berarti konsumsi tablet fe berhubungan dengan kejadian anemia pada ibu hamil di di Puskesmas Sanrobone Kabupaten Takalar 2016.

4. Hubungan Asupan gizi dengan Kejadian Anemia Pada ibu hamil

Tabel 4. Hubungan Asupan gizi dengan Kejadian Anemia Pada Ibu Hamil Di Puskesmas Sanrobone Kabupaten Takalar

\begin{tabular}{|c|c|c|c|c|c|c|c|c|}
\hline \multirow{3}{*}{ Variabel } & \multicolumn{4}{|c|}{ Status Ibu Hamil } & \multirow{2}{*}{\multicolumn{2}{|c|}{ Total }} & \multirow{3}{*}{$X^{2}$} & \multirow{3}{*}{$p$} \\
\hline & \multicolumn{2}{|c|}{ Anemia } & \multicolumn{2}{|c|}{ Tidak Anemia } & & & & \\
\hline & $\mathbf{n}$ & $\%$ & $\mathbf{n}$ & $\%$ & $\mathbf{n}$ & $\%$ & & \\
\hline Asupan Gizi & & & & & & & \multirow{4}{*}{14.354} & \multirow{4}{*}{0.000} \\
\hline $\begin{array}{ll}\begin{array}{l}\text { Tidak } \\
\text { gonsumsi }\end{array} & \text { Men- } \\
\end{array}$ & 32 & 80.0 & 8 & 27.1 & 40 & 100 & & \\
\hline Mengonsumsi & 6 & 30.0 & 14 & 75.0 & 20 & 100 & & \\
\hline Total & 38 & 63.3 & 22 & 36.7 & 60 & 100 & & \\
\hline
\end{tabular}

Sumber : Data Primer, 2016

Tabel 4 menunjukkan bahwa dari 40 ibu hamil yang menyatakan tidak mengkonsumsi asupan gizi, terdapat yang menderita anemia sebanyak 80,0\%. Sedangkan dari 20 ibu hamil yang menyatakan mengkonsumsi asupan gizi, terdapat yang menderita anemia sebanyak 30,0\%. Hasil analisis statistik diperoleh nilai $X^{2}$ hitung $(14,354)>X^{2}$ tabel $(3,841)$ dan nilai $p(0,000)<0,05$. Ini berarti asupan gizi berhubungan dengan kejadian anemia pada ibu hamil di Puskesmas Sanrobone Kabupaten Takalar 2016.

Analisis multivariat dilakukan untuk menentukan variabel yang paling berhubungan dengan kejadian anemia pada ibu hamil, setelah dianalisis dengan variabel lainnya. Variabel yang masuk kedalam model adalah yang bermakna secara statistik (nilai $\mathrm{p}<0,05$ ). Berdasarkan model akhir regresi logistik terlihat bahwa variabel yang berhubungan dengan kejadian anemia pada ibu hamil di di Puskesmas Sanrobone Kabupaten Takalar 2016. 
adalah variabel pola makan, pantangan makanan, konsumsi tablet Fe dan pemberian makanan tambahan. Analisis multivariat dapat dilihat pada tabel berikut ini :

Tabel 5. Analisis Multivariat Kejadian Anemia Pada Ibu Hamil Di Puskesmas Sanrobone Kabupaten Takalar

\begin{tabular}{lllllll}
\hline Variabel & B & S.E & Wald & Df & Sig. & Exp(B) \\
\hline Pola Makan & -1.561 & 1.033 & 2.282 & 1 & 0.131 & 0.21 \\
\hline Pantangan Makanan & 0.887 & 0.837 & 1.123 & 1 & 0.289 & 2.427 \\
\hline Pemberian Tablet Fe & 2.043 & 1.009 & 4.102 & 1 & 0.043 & 7.712 \\
\hline Asupan Gizi & 1.031 & 0.886 & 1.355 & 1 & 0.244 & 2.804 \\
\hline Constant & -1.532 & 0.441 & 12.077 & 1 & 0.001 & 0.216 \\
\hline
\end{tabular}

Sumber data Primer, 2016

Tabel 5 menunjukkan bahwa pola makan (nilai $\mathrm{p}=0,757$ ) tidak berhubungan dengan kejadian anemia pada ibu hamil. Sedangkan pantangan makanan (nilai $p=0,005$ ), konsumsi tablet Fe (nilai $p=0,000$ ), asupan Gizi (nilai $p=0,000$ ) berhubungan dengan kejadian anemia pada ibu hamil. Dari ketiga variabel tersebut variabel yang paling berhubungan dengan kejadian anemia pada ibu hamil adalah variabel pemberian tablet fe dengan nilai expected $=7.712$.

\section{PEMBAHASAN}

1. Hubungan Pola Makan dengan Kejadian Anemia Pada Ibu Hamil

Makanan merupakan substansi yang dimasukkan dalam tubuh yang akan membantu tubuh memenuhi kebutuhan energi, pemeliharaan kesehatan, pertumbuhan, dan reproduksi. Makanan merupakan sesuatu yang esensial bagi kehidupan manusia. Manusia membutuhkan makanan untuk bisa beraktifitas sehari-hari. Oleh karena itu pentingnya makanan yang sangat besar. Manusia memiliki pola makan yang berbeda untuk dapat beraktifitas sehari-hari. Pola makan merupakan berbagai informasi yang memberikan gambaran mengenai macam dan jumlah bahan makanan yang dimakan [5].

Hasil penelitian ini sesuai dengan penelitian yang dilakukan oleh Rismawati di Kelurahan Somba Opu Kabupaten Gowa tahun 2010 menyatakan bahwa tidak ada hubungan pola makan dengan kejadian anemia pada ibu hamil [6].

Pola makan yang baik harus memenuhi prinsip gizi seimbang dan sehat, yaitu hidangan yang terdiri dari makanan pokok, lauk pauk, sayur-sayuran dan buah-buahan. Mengingat bahwa fungsi makanan bagi tubuh adalah untuk menyediakan tenaga, keperluan pertumbuhan, pemeliharaan, dan pengganti jaringan yang rusak. Namun dewasa ini, keputusan memilih makanan pada kebanyakan orang bukanlah karena nilai gizinya, melainkan cita rasa, budaya dan ketersediaan makanan itu sendiri [7].

Masukan zat besi setiap hari diperlukan untuk mengganti zat besi yang hilang melalui tinja, air kencing dan kulit. Kehilangan basal ini kira-kira 14 ug per Kg berat badan per hari atau hampir sarna dengan 0,9 mg zat besi pada laki-laki dewasa dan 0,8 mg bagi wanita dewasa. Kebutuhan zat besi pada ibu hamil berbeda pada setiap umur kehamilannya, pada trimester I naik dari 0,8 mg/hari, menjadi 6,3 mg/hari pada trimester III. Kebutuhan akan zat besi sangat menyolok kenaikannya. Dengan demikian kebutuhan zat besi pada trimester II dan III tidak dapat dipenuhi dari makanan saja, walaupun makanan 
yang dimakan cukup baik kualitasnya dan bioavailabilitas zat besi tinggi, namun zat besi juga harus disuplai dari sumber lain agar supaya cukup [8].

Penambahan zat besi selama kehamilan kira-kira 1000 mg, karena mutlak dibutuhkan untuk janin, plasenta dan penambahan volume darah ibu. Sebagian dari peningkatan ini dapat dipenuhi oleh simpanan zat besi dan peningkatan adaptif persentase zat besi yang diserap. Tetapi bila simpanan zat besi rendah atau tidak ada karena sekali dan zat besi yang diserap dari makanan sangat sedikit maka, diperlukan suplemen preparat besi. Dalam jumlah kebutuhan zat besi sehari yang dianjurkan telah termasuk perhitungan tingkat absorbsi zat besi yang berasal dari diet yang biasa dimakan. sumber yang lebih penting dan ditemukan dalam tingkat yang berbeda-beda pada seluruh makanan yang berasal dari tumbuhtumbuhan seperti sayur -sayuran, buah-buahan, biji-bijian dan kacang-kacangan serta serealia, dalam jumlah yang sedikit terdapat di dalam daging, telur dan ikan [8].

Zat besi selain diperoleh dari bahan makanan, juga bisa dari makanan mengandung zat besi eksogen, yang berasal dari tanah, debu dan air atau panci tempat memasak. Keadaan ini lebih sering terjadi di negara yang sedang berkembang. Jumlah zat besi cemaran di dalam makanan mungkin beberapa kali lebih besar dibandingkan dengan jumlah zat besi dalam makanannya sendiri. Memasak makanan di dalam panci besi bisa meningkatkan kandungan zat besi beberapa kali lipat, terutama sup yang mngandung sayuran yang mempunyai $\mathrm{pH}$ rendah dan dididihkan terlalu lama. Menggoreng dengan kuali besi biasanya tidak meningkatkan kandungan zat besi dalam makanan. Zat besi yang dilepas selama memasak akan berikatan dengan kelompok zat besi, dan siap untuk diserap. Bentuk lain zat besi eksogen terdapat dalam makanan seperti gandum, gula dan garam yang telah diperkaya dengan zat besi atau garam besi.

2. Hubungan Pantangan Makanan dengan Kejadian Anemia Pada ibu hamil

Kehamilan merupakan suatu masa yang sangat dinantikan oleh wanita yang sudah menikah terutama oleh pasangannya, karena dengan sang wanita mengalami kehamilan maka akan menjadikan hubungan diantara mereka semakin lengkap dengan hadirnya sesosok bayi kecil yang melengkapi kehidupan rumah tangga mereka. Namun, kehamilan juga merupakan suatu masa yang sangat sulit untuk di jalani karena ibu hamil akan merasakan berbagai perubahan baik secara fisik maupun mental. Pada saat hamil juga banyak sekali makanan yang harus di hindari demi menjaga kesehatan bayi dan ibunya.

Hal ini disebabkan banyaknya pantangan terhadap makanan yang dikonsumsi si ibu baik pada saat hamil maupun sesudah melahirkan [9].

Penelitian ini sejalan dengan penelitian yang dilakukan oleh Irmalia di Rumah Sakit Bersalin Pertiwi Makassar tahun 2003 menyatakan bahwa ada hubungan pantangan dengan kejadian anemia pada ibu hamil. Seperti [10]:

a. Daging Mentah Atau Setengah Matang

Selama proses kehamilan berlangsung ada baiknya jikalau ibu hamil menghindari makanan daging terlebih dahulu terutama daging menta atau setengah matang ( sate atau daging bakar ). Hal tersebut di karenakan daging mentah tersebut mengandung bakteri seperti Sallmonela dan Toxoplasma. Toxoplasma merupakan suatu virus yang terdapat pada kucing, virus ini akan tertular 
melalui kambing atau sapi yang kebetulan memakan kotoran kucing yang ada di rumput sehingga kambing tersebut terinfeksi virus toxoplasma. Walaupun tidak semua daging kambing dan sapi terinfeksi virus tersebut namun ibu harus tetap teliti dan waspada.

b. Makanan Yang Mengandung Bahan Pengawet

Makan yang mengandung bahan pengawet (makanan cepat saji) memang memiliki rasa yang enak, namun makanan tersebut tidak di anjurkan untuk ibu hamil. Makanan yang mengandung bahan pengawet yang tidak boleh di konsumsi oleh ibu hamil yaitu : Mie Instant, Sarden, Sosis, Kornet ataupun makanan jajanan di pasaran seperti bakso yang memakai boraks dan lain sebagainya. Pengawet tersebut sangat berbahaya bagi perkembangan janin dan bisa berefek menghambat pertumbuhan saraf saraf otak janin.

c. Mie Instant Dan Cemilan Ringan

Seperti yang sudah di bahas tadi, bahwa mie instant memiliki pengawet yang bisa membahayakan si jabang bayi. Bukan hanya itu mie instant yang gurih tersebut mengandung MSG yang dapat memberikan dampak negatif terhadap janin. Efek samping kebanyakan makan MSG sendiri yaitu kepala pusing, jantung berdebar, dan sesak nafas. Bagi calon bayi MSG bisa menyebabkan kerusakan sel saraf baik bayi tersebut belum lahir maupun ketika lahir.

d. Alkohol

Minuman ini memang tidak hanya berbahaya bagi ibu hamil tetapi juga setiap orang pad umumnya. Alkohol dapat mengakibatkan gangguan mental bagi bayi serta gangguan kehamilan lainnya.

e. Kafein

Kafein biasanya akan di temukan pada minuman seperti teh dan kopi namun yang namun kafein lebih sering di temukan pada kopi. Jika terlalu sering mengkonsumsi kafein makan akan berefek kepada terjadinya keguguran terutama pada masa masa trisemester. Tidak jarang banyak orang yang mewanti wanti setiap ibu hamil agar tidak mengkonsumsi kafein yang menjadikan kafein ini sebagai pantangan besar bagi ibu hamil pada umumnya. Senyawa dari kafein dapat menyebabkan tubuh lemas, dehidrasi, dan kekurangan kalsium.

f. Rokok

Sudah jelas terpapang dalam kemasan produk rokok yang tertulis " merokok dapat menyebabkan gangguan kehamilan yang membahayakan janin " sehingga rokok sangat harus di hindari oleh ibu hamil.

Penelitian ini sesuai dengan penelitian yang dilakukan oleh Rismawati di Kelurahan Somba Opu Kabupaten Gowa tahun 2010 menyatakan bahwa ada hubungan pantangan makanan dengan kejadian anemia pada ibu hamil.

3. Hubungan Konsumsi Tablet Fe dengan Kejadian Anemia Pada ibu hamil

Pada ibu hamil dengan usia muda masih membutuhkan asupan gizi yang banyak kemudian di tambah dengan kehamilan, berarti zat gizi yang diterima harus dibagi antara si ibu dan janin, yang 
nantinya ibu akan mengalami kekurangan satu atau lebih zat gizi yang akhirnya menimbulkan salah satunya adalah anemia. Sedangkan ibu hamil pada usia terlampau tua ( $>35$ tahun), fungsi organ tubuhnya yang telah mengalami kemunduran atau degenerasi, oleh karena itu selama kehamilan hemoglobin dalam sel darah merah mengalami penurunan. Hal ini disebabkan ketidak mampuan organ untuk menyerap makanan secara sempurna, salah satunya zat besi dan menyenankan anemia [11].

Penelitian ini sejalan yang dilakukan oleh Indriani di wilayah kecamatan Somba Opu tahun 2002 menyatakan bahwa ada hubungan konsumsi tablet fe dengan kejadian anemia pada ibu hamil. Jenis makanan yang baik adalah yang mengandung zat gizi lengkap yaitu sumber karbohidrat, protein, vitamin b dan mineral, seperti arem-arem nasi isi daging sayuran, tahu isi daging sayuran, roti isi ragout ayam sayuran, piza, dan lain-lain. Makanan selingan yang baik di buat sendiri dirumah sehingga sangat higienis dibandingkan jika bibeli di luar rumah [2].

Penelitian ini sejalan dengan penelitian yang dilakukan oleh Irmalia di Rumah Sakit Bersalin Pertiwi Makassar tahun 2003 menyatakan bahwa ada hubungan konsumsi tablet fe dengan kejadian anemia pada ibu hamil [10].

Asam folat juga penting dalam membantu pembelahan sel. Asam folat juga bisa mencegah anemia dan menurunkan risiko terjadinya NTD (Neural Tube Defects) dan sebagai antidepresan. Sering kali para ibu tidak mengetahui dirinya kekurangan asam folat karena sebagian besar kehamilan terjadi tanpa direncanakan. Karena itu, ibu pun sering tidak membekali diri dengan gizi yang mencukupi ketika sebelum dan sesudah kehamilan. "Kalau kehamilan direncanakan, maka ia akan mempersiapkan gizi yang baik sebelum hamil. Padahal, kebutuhan asam folat untuk ibu hamil harus disiapkan sejak sebelum kehamilan [12].

Di Indonesia sendiri belum ada data pasti berapa besarnya prevalensi adanya penyakit kelainan sumsum tulang belakang. "Jumlah angka kematian bayi di Indonesia masih relatif tinggi. Kematian bayi ini belum diidentifikasi penyebabnya apa, karena belum ada data. Salah satu penyebab kematian bayi adalah kekurangan asam folat. Kekurangan asam folat menyebabkan bayi lahir dengan bibir sumbing, bayi dengan berat badan rendah, Down's Syndrome, dan keguguran. Bayi mengalami kelainan pembuluh darah. Rusaknya endotel pipa yang melapisi pembuluh darah, menyebabkan lepasnya plasenta sebelum waktunya."Kelainan lainnya adalah bayi mengalami gangguan buang air besar dan kecil, anak tidak bisa berjalan tegak dan emosi tinggi. Pada anak perempuan saat dewasa tidak mengalami menstruasi.Pada ibu hamil kekurangan folat menyebabkan meningkatnya risiko anemia, sehingga ibu mudah lelah, letih, lesu, dan pucat [13].

Sumber makanan yang mengandung asam folat adalah hati sapi (liver), brokoli, jeruk, bayam, dan sebagainya. "Roti dan susu juga mengandung asam folat tinggi, sebab kini susu dan tepung terigu telah difortifikasi mengandung asam folat, Department of Human Nutrition University of Otago New Zealand Hanya saja hati sapi mengandung vitamin A cukup tinggi. Pemberian vitamin A pada ibu hamil sangat tidak dianjurkan karena menyebabkan gangguan kehamilan. Oleh sebab itu, pengganti hati sapi adalah susu.Kebutuhan asam folat untuk ibu hamil dan usia subur sebanyak 400 mikrogram/hari atau sama 
dengan dua gelas susu. "Mengonsumsi folat tidak hanya ketika hamil, tetapi sebelum hamil sangat dianjurkan. Banyak negara telah melakukan kebijakan dalam pengurangan NTD dengan mewajibkan ibu mengonsumsi asam folat.

Jumlah zat besi di dalam tubuh orang dewasa sehat adalah lebih kurang sebanyak 4 gram. Sebagian besar yaitu 2,5 gram berada di dalam sel-sel darah merah atau hemoglobin. Zat besi yang terdapat di dalam pigmen pada otot disebut myoglobin yang berfungsi untuk menangkap dan memberikan oksigen. Enzim intraselluler yang disebut phorphyrin juga mengandung zat besi. Enzim lain yang terpenting diantaranya adalah cytochrome yang selalu banyak terdapat di dalam sel. Pada orang yang sehat. sebagian zat besi yaitu lebih kurang 1 gram disimpan didalam hati yang berikatan dengan protein yang disebut ferritin [7].

Didalam tubuh zat besi mempunyai fungsi yang berhubungan dengan pengangkutan, penyimpanan dan pemanfaatan oksigen yang berada dalam bentuk hemoglobin. myoglobin atau cytochrome. Untuk memenuhi kebutuhan guna pembentukan hemoglobin. sebagian besar zat besi yang berasal dari pemecahan sel darah akan dimanfaatkan kembali. kemudian baru kekurangannya harus dipenuhi dan diperoleh melalui makanan. Keseimbangan zat besi di dalam tubuh perlu dipertahankan yaitu jumlah zat besi yang dikeluarkan dari tubuh sarna dengan jumlah zat besi yang diperoleh tubuh dari makanan. Bila zat besi dari makanan tidak mencukupi. maka dalam waktu lama akan mengakibatkan anemia. Sel-sel darah merah berumur 120 hari. jadi sesudah 120 hari sel-sel darah merah mati. dan diganti dengan yang baru. Prosespenggantian sel darah merah dengan sel-sel darah merah baru disebut turn over [14].

Penelitian ini sesuai dengan penelitian yang dilakukan oleh Rismawati di Kelurahan Somba Opu Kabupaten Gowa tahun 2010 menyatakan bahwa ada hubungan konsumsi tablet fe dengan kejadian anemia pada ibu hamil [6].

4. Hubungan Asupan gizi dengan Kejadian Anemia Pada ibu hamil

ibu hamil asupan gizi yang seimbang merupakan modal awal dalam Asupan Nutrisi adalah Makanan dengan gizi yang cukup merupakan kebutuhan individu, setiap makanan memiliki gizi yang berbeda sehingga harus cermat dalam memilih makananan setiap hari untuk memenuhi kecukupan gizi sesuai dengan kebutuhan. Keseimbangan gizi adalah terpenuhinya zat gizi baik secara mikro ataupun makro yang dibutuhkan sesuai dengan masing-masing individu. Bagi memberikan kehidupan yang terbaik selama janin berkembang di dalam kandungan [15].

Gizi dan Nutrisi ibu hamil merupakan hal penting yang harus dipenuhi selama kehamilan berlangsung. Resiko akan kesehatan janin yang sedang dikandung dan ibu yang mengandung akan berkurang jika ibu hamil mendapatkan gizi dan nutrisi yang seimbang. Oleh karena itu, keluarga dan ibu hamil haruslah memperhatikan mengenai hal ini. Gizi atau nutrisi ibu hamil kondisinya sama saja dengan pengaturan gizi mengenai pola makan yang sehat. Cuman saja, ibu hamil harus lebih hati-hati dalam memilih makanan karena mengingat juga kesehatan janin yang sedang dikandungnya [15]. 
Bersama dengan usia kehamilan yang terus bertambah, makan bertambah pula kebutuhan gizi dan nutrisi ibu hamil, khususnya ketika usia kehamilan memasuki trimester kedua. Pada saat trimester kedua, janin tumbuh dengan sangat pesat, khususnya mengenai pertumbuhan otak berikut susunan syarafnya.

Agar perkembangan janin berjalan dengan baik, dan ibu hamil dapat menjalani hari-hari kehamilannya dengan sehat, makan konsumsi ibu hamil harus mengandung gizi sebagai berikut: Kalori. Asam Folat. Protein, Kalsium, Vitamin A, Zat Besi, Vitamin C dan Vitamin D [7].

Jika ibu hamil tidak mengalami berbagai macam gejala seperti anemia, gusi berdarah dan gejala lainnya, maka ibu hamil tersebut dapat dikatakan telah mencukupi kebutuhan akan gizi dan nutrisinya. Hal yang lebih penting untuk mengecek kecukupan nutrisi selama kehamilan adalah tentunya melalui perkembangan berat badan selama kehamilan. Tentunya kenaikan berat badan berbeda-beda tiap bulannya.

Namun bagaimana jika selama kehamilan ibu hamil mengalami kekurangan asupan gizi ? maka jal ini bias berdampak pada terjadinya bayi terlahir secara premature, mengakibatkan keguguran, adanya kelainan bayi dalam system syarafnya, janin berkembang tidak normal, bahkan menyebabkan hingga kematian janin. Jadi perhatika betul mengenai asupan gizi selama kehamilan. Yang berlu diingat, janganlah memenuhi kebutuhan gizi dan nutrisi karena kuantitas, tapi gizi yang berkualitas dengan komposisi yang berimbang dan cukup, itu yang terpenting.

Penelitian ini sejalan dengan penelitian yang dilakukan oleh Irmalia di Rumah Sakit Bersalin Pertiwi Makassar tahun 2003 menyatakan bahwa ada hubungan Asupan Gizi dengan kejadian anemia pada ibu hamil [10].

\section{KESIMPULAN DAN SARAN}

Berdasarkan hasil penelitian maka disimpulkan bahwa pola makan tidak berhubungan dengan kejadian anemia pada ibu hamil di puskesmas sanrobone kabupaten takalar. Sedangkan pantangan makanan, konsumsi tablet fe, dan asupan Gizi berhubungan dengan kejadian anemia pada ibu hamil di Puskesmas Sanrobone Kabupaten Takalar.

Diharapkan kepada ibu hamil mengatur pola makannya terutama makanan yang mengandung zat gizi lengkap serta mengatur dan mengkonsumsi asupan gizi dengan baik dan benar terutama makanan yang mengandung zat gizi yang diberikan dari petugas kesehatan.

\section{DAFTAR PUSTAKA}

[1] Maeyer. Em. De, Pencegahan Dan pengawasan Anemia Defisiensi Besi. Terjemahan Oleh Arisunan. Jakarta: Widya Medika, 1995.

[2] Indriani, "Faktor Yang Berhubungan Dengan Kejadian Anemia Pada Ibu Hamil Di Kecamatan Somba Opu," 2002.

[3] Dinas Kesehatan Sulawesi Selatan, Profil Puskesmas. Makassar: Dinas Kesehatan Sulawesi Selatan, 2007.

[4] dkk. Singarimbun, Masri, Metode Penelitian Survei. Jakarta: Pustaka LP3ES Indonesia, 1999.

[5] PERSAGI, Penuntun Diet, 2nd ed. Jakarta: Gramedia, 2001.

[6] Rismawati, "Penelitian Faktor Yang Berhubungan Dengan Kejadian Anemia Pada Ibu Hami Di Kelurahan Somba Opu Kabupaten Gowa," 2010.

[7] Depkes RI, Petunjuk Teknis Tatalaksana Anak Gizi Buruk, 2nd ed. Jakarta: Direktorat Bina Gizi Masyarakat, 2006. 
[8] D. Moejhi, Pengetahuan Dasar Ilmu Gizi. Jakarta: Gramedia, 2002.

[9] A. Berg, Peranan Gizi Dalam Pembangunan Nasional. Jakarta: CV. Rajawali, 1990.

[10] Irmalia, "Faktor Yang Berhubungan Dengan Kejadian Anemia Pada Ibu Hamil Di Rumah Sakit Bersalin Pertiwi," 2003.

[11] dkk. Soegeng, Santoso, No Title, 2nd ed. Jakarta: Rineka Cipta, 2004.

[12] Anonim, “Nutrisi Pada Ibu Hamil," 2009. [Online]. Available: blogspot.com. [Accessed: 15-Jan-2010].

[13] Depkes RI, Komposisi Zat Gizi Makanan Indonesia. Jakarta: Direktorat Bina Gizi Masyarakat. Bogor, 2001.

[14] dkk. Francin E, Paath, Gizi Dalam Kesehatan Reproduksi. Jakarta: EGC, 2004.

[15] F. Zuhritun N, “Korelasi antara Asupan Makanan, Tingkat Pengatahuan, Pelayanan Kesehatan dan Sanitasi lingkungan dengan Status Gizi di Pesantren X Yogyakarta," 2005. 